anthropology \& materialism

\section{Anthropology \& Materialism}

A Journal of Social Research

4 | 2019

Art and Technique: A Framework of Unaccomplished Promises

\title{
Walter Benjamin's Concept of Technique
}

Le concept de technique chez Walter Benjamin

El concepto de técnica en Walter Benjamin

\section{Jan Sieber}

\section{OpenEdition}

\section{Journals}

Édition électronique

URL : https://journals.openedition.org/am/944

DOI : 10.4000/am.944

ISSN : $2364-0480$

Éditeur :

CETCOPRA, CRASSH - Center for Research in the Arts Social Sciences and Humanities, Fakultät

Gestaltung - Universität der Künste Berlin

Référence électronique

Jan Sieber, «Walter Benjamin's Concept of Technique », Anthropology \& Materialism [En ligne], 4| 2019, mis en ligne le 13 octobre 2019, consulté le 08 septembre 2021. URL : http://journals.openedition.org/ am/944; DOI : https://doi.org/10.4000/am.944

Ce document a été généré automatiquement le 8 septembre 2021.

Tous droits réservés 


\title{
Walter Benjamin's Concept of Technique
}

\author{
Le concept de technique chez Walter Benjamin \\ El concepto de técnica en Walter Benjamin
}

Jan Sieber

\section{NOTE DE L'ÉDITEUR}

This text is the original extended version of what has been translated and edited in spanish by Marc Berdet and Esther Cohen, in: Jan Sieber. „Técnica.“ Glosario Walter Benjamin. Conceptos y figuras, edited by Esther Cohen. Mexico: UNAM, 2016, pp. 209-218.

\section{1. [An attempt of a short definition of technique in Walter Benjamin] $]^{1}$}

1 Benjamin's concept of technique describes a practical relation to the world, implying special ontological, historical, political and aesthetic dimensions, across which Benjamin differentiates between a "first" (at first sight "traditional") and a "second" technique (at first sight "modern"), for which the measure is instrumental and noninstrumental use.

2 Ontologically, technique entails the constitution of the being of the profane world through humanity as a collective. It constitues the medium in which humanity carries out its task to constructively transform and to give shape to the world. As this world, throughout its transformations, is historical, so is technique as the medium for that task. For this reason, Benjamin's concept of technique can be said to be nontechnological; in other words, technique doesn't name neither one single technological apparatus nor the sum of all technologies available at one given time. It appointed rather the practical relation to the world as a medium that historically entails different 
practices and technologies. This historical ontological transformation of the profane world constitutes technique's political dimension. Technique is the medium in which humanity shapes the world as well as its social relations with happiness as its aim. Such happiness, as the kernel of techniques political dimension and as aim of all worldly practices, is not a state, not an end, but rather what, in history, always anew and again will have been lost. Happiness as the political $a$-telos of technique is at the same time the a-topos of the world created in and through technique, it corresponds to that nonplace in the world where what exists in the world is not yet. Happiness is humanity's infinite task to which technique is the medium. The realm of art relates to technique in a special way. Art, from the perspective of technique, is a space where humanity is able to freely rehearse new uses of new technologies and experiences related to it. It can thus have an exemplary and precursory function regarding the task of humanity to give shape to the world in the medium of technique.

3 Across these ontological, historical, political and aesthetic dimensions, Benjamin differentiates between two modes of technique. These don't constitute two separate worlds, but rather two opposite poles of one and the same medium. They are always intertwined as two simultaneous possibilities. The measure of their difference consists in instrumental or non-instrumental use. The former is inadequate insofar it employs technique as a mere means to an end alien to itself, as a mere instrument of domination and exploitation. Making a non-instrumental use is adequate to technique as a medium, adequate to the mediality of technique. Thus Benjamin significantly departs from the classical concept of techne as a target-oriented and rule-governed ability bound to a certain positive knowledge. Technique is instead a non-instrumental medium in which humanity practically and constructively gives shape to world with the aim of happiness.

\section{2. [How the conception of technique evolves along Benjamin's writing]}

4 Benjamin's reflections on technique span from his early till his later writings. A significant shift occurs in the mid 1920s - the shift that Benjamin himself called a political turning point in his work - which separates as well as connects his early metaphysical-theological and his later materialist concept of technique.

5 Benjamin's earliest, explicit reflections on technique are situated in the context of his large project on politics on which he worked on between 1918 and 1921/22. Technique here figures as one of the central concepts in Benjamin's political theory, alongside his metaphysics of a collective body (Leib) as political subject and his notion of the Messianic, distinguishing the political from religion, law and morals. True politics, for Benjamin, is limited to the order of the profane, and not directed towards a redemptive identity of worldly history and divine kingdom. Furthermore, as he writes in the Theological-Political Fragment from 1920/21, the "order of the profane should be erected on the idea of happiness" (SW $\left.3^{2}, 305\right) .^{3}$ Politics has no end outside itself but exclusively concentrates itself on the organization of worldly happiness. The political subject of this profane striving is humanity as a collective which organizes itself in a collective body. In history this collective body transforms and extends itself through the inclusion of nature through technique. Benjamin describes this nexus of politics, happiness, collective body and technique in his Schemata on the psycho-physical Problem: 
"In addition to the totality of all its living members, humanity is able partly to draw nature, the nonliving, plant and animal, into this life of the body of mankind, and thereby into this annihilation and fulfillment. It can do this by virtue of technique in which the unity of its life is formed. Ultimately, everything that subserves humanity's happiness may be counted part of its life, its limbs" (SW 1, 395). ${ }^{4}$

Technique mediates between humanity's profane striving for happiness and the life of the collective body. It forms the medium in which mankind integrates nature into the collective body on behalf of its quest for happiness.

7 Benjamin's early concept of technique is considerably inspired by Paul Scheerbart's novel Lesabéndio which he read around 1917/ 1918. ${ }^{5}$ As Benjamin was planning it, a comment on Lesabéndio would have been a fitting conclusion to his (unfinished) work on politics insofar as the novel conceives an idea of a productive, harmonious interplay between man and nature via technique. He calls the novel an "utopia of the collective body"6 which envisions the intermingling of mankind and nature in one body through technical artistic design. Even later in 1926/27, Benjamin emphasises the "pathos of technique", the "pathos of the machine"7 of Scheerbart's novels. His fictional characters are "makers of machines and creators of an ideal technique"8. For Benjamin "no other author had so clearly emphasized the revolutionary character of technological achievement"9 as Scheerbart did. He claims that man should abandon the idea that he is destined to master and exploit the forces of nature, and, instead, convince himself that technique has the potential to liberate him, together with nature.

Around 1924/25, Benjamin's early concept of technique takes a critical turn which insists more on the destructive powers of modern technology. One-Way Street is a critique of the reactionary and alienated lifestyle of the German bourgeoisie and the "general failure" (SW 1, 453) ${ }^{10}$ of Weimar Germany. In the last aphorism, entitled "To the Planetarium", Benjamin draws a conceptual trajectory from ancient times to his own present and for the first time develops an anthropological materialist rather than metaphysical argument concerning technique. ${ }^{11}$ In modernity, Benjamin argues, cosmic experience by which in antiquity man communicated with nature through intoxication and collective rituals is lost. But for Benjamin, it has by no means vanished irretrievably, more willingly it has transformed. And the first time it manifested itself in its new form is the First World War, "an attempt at a new and unprecedented commingling with the cosmic powers"(SW 1, 486)..$^{12}$ Benjamin goes on to argue that "this immense wooing of the cosmos was enacted for the first time on a planetary scale, that is, in the spirit of technology"(SW 1, 486-7). ${ }^{13}$ With the development of modern technologies, transport systems, techniques of reproducibility, telecommunication technologies etc., cosmic experience transitioned into technique as its new medium. But "because the lust for profit of the ruling class sought satisfaction through it, technology betrayed man and turned the bridal bed into a bloodbath"(SW 1, 487).14

This problem of a bad technique, one that takes revenge on mankind, Benjamin develops further in Theories of German Fascism. "Any future war will also be a slave revolt on the part of [technique] [...]"(SW 2, 312). ${ }^{15}$ According to Benjamin, technique demands a revolution of the social relations, because it aims at a fundamentally different relation between man and nature as that of domination and exploitation: "[Technique] [...] is the mastery of not nature but of the relation between nature and man"(SW 1, 487). ${ }^{16}$ But the capitalist relations of production prevent an emancipatory use of technique. And because its "right of determination in the social order" is denied, technique abdicates from a "harmonious interplay" (SW 2, 312) ${ }^{17}$ The emancipatory 
potential of technique turns into its very opposite. Every war, Benjamin argues, is always an evidence "that social reality was not ready to make [technique] [...] its own organ, and that [technique] [...] was not strong enough to master the elemental forces of society"(SW 2, 312). ${ }^{18}$ The missed chance of a revolution, of taking hold of technique's potential, takes revenge... in war. ${ }^{19}$

In The Work of Art in the Age of its Technological Reproducibility, Benjamin develops further this difference between a good and a bad use of technique's potential into the anthropological materialist concept of a first and a second technique. ${ }^{20}$ Moreover, he relates technique to the sphere of art and connects it to the notion of play. Technique as well as art, Benjamin argues, have the same origin in ritual. The earliest objects that stood in the service of magic can neither be called technique nor art but they both originate in religion. Only in the course of history they separated. As two different spheres they are both historically determined by a tension between two extremes; in art, this tension is build between a "cult value" and an "exhibition value", respectively semblance and play; in technique, this tension deploys itself between a "first" and a "second technique", i. e. the mastery of nature on the one hand, the interplay between man and nature on the other. It is by shifting from one pole to another that art correlates with technique. "The scope for exhibiting the work of art has increased so enormously with the various methods of technologically reproducing it that, as happened in prehistoric times, a quantitative shift between two poles of the artwork has led to a qualitative transformation in its nature" (SW 4, 257). ${ }^{21}$ In modernity, Benjamin seems to suggest, art is ahead of technique insofar as it has already enacted the qualitative shift from cult value to exhibition value, from the primacy of semblance to the primacy of play. That is, art has already done the qualitative leap that in the sphere of technique is bound to the transformation of the relations of production. Therefore, Benjamin claims that "the primary social function of art today is to rehearse that interplay" (SW 3, 107-8) $)^{22}$ between man and nature which second technique makes possible. This is precisely the political function of art. Art teaches man that technique will release him from his "enslavement to the powers of the apparatus only when humanity's whole constitution has adapted itself to the new productive forces which the second [technique] [...] has set free" (SW 3, 108). ${ }^{23}$

Benjamin describes this as the "world historical conflict between first and second technique" (SW 3, 127). ${ }^{24}$ The former makes

the maximum possible use of human beings, [whereas] the latter reduces their use to the minimum. The achievements of the first [technique] [...] might be said to culminate in human sacrifice; those of the second, in the remote-controlled aircraft which needs no human crew. The results of the first [technique] [...] are valid once and for all (it deals with irreparable lapse or sacrificial death, which holds good for eternity). The results of the second are wholly provisional (it operates by means of experiments and endlessly varied test procedures) (SW 3, 107). ${ }^{25}$

12 "First technique" is intrinsically related to mythical power relations, regardless whether it expresses the mastery of man by nature (in prehistory) or the mastery of nature by man (in modernity). The origin of "second technique" resides in play through which human beings "by an unconscious ruse, [...] first began to distance themselves from nature" (SW 3, 107). ${ }^{26}$

13 In modernity this "world-historical conflict between first and second technique" culminates in the most intense contradiction between the forces and the relations of production. By the mid 1930s, against the background of his experiences with fascism 
in Germany, his exile and the development in Russia, Benjamin saw only two ways in which the crisis could proceed: fascism or communism, war or revolution. This, famously, is the political framework of the Artwork-Essay. Fascism tries to organize the masses without changing the relations of property. "It sees its salvation in granting expression to the masses - but on no account granting them rights" (SW 3, 121). ${ }^{27}$ Consequently, fascism is also interested "in keeping secret the true functional character of technique". ${ }^{28}$ Emancipatory revolutions, on the other hand, "are innervations of the collective - or, more precisely, efforts at innervation on the part of the new, historically unique collective which has its organs in the new [technique] [...]" (SW 3, 124). ${ }^{29}$ Utopian demands, like the ones formulated by Fourier and Scheerbart, are for Benjamin prophetic expressions of the potential of a playful, experimental and constructive use of technique. Moreover, in the sphere of art, the collective can already in the present practice such a playful use. Art serves as a space for rehearsal in which the collective can experience how little it has realized his quest for happiness under the spell of the first technique and become familiar with the new "room for play" (Spielraum) opened up by the second technique. But only through a revolutionary transformation of the relations of production can the collective body make technique one of its organs and realize its potential in a playful interplay between mankind and nature.

14 To resume, across his intellectual development in the 1920s and 1930s, Benjamin's concept of technique is marked by discontinuities as well as continuities. His argumentation changes from a metaphysical conceptualization of technique's potential into an anthropological-materialist one. Benjamin's theoretical apparatus transforms itself, but the philosopher holds on to his notion of technique as a non-instrumental means of the relation between man and nature, of an harmonious interplay in its medium. In his later writings this ideal is problematized. It is confronted with the problem of the use of technique for the purpose of domination and exploitation of man and nature under capitalism. The degradation of technique to a means of exploitation and domination in the capitalist mode of production prevents the unfolding of its true potential.

\section{3. [The contemporary reception of Benjamin's problematization of technique]}

15 Different from Max Weber, Martin Heidegger, or T. W. Adorno and Max Horkheimer, Benjamin does not formulate his concept of technique in relation to the modern concept of rationalist subjectivity for which the natural sciences are the role model. Rather, he criticizes such a perception insofar it takes technique to be merely an expression of instrumental reason.

16 Therefore, I want to argue conclusively that Benjamin thought of technique as a noninstrumental medium which is structured like a language. Already in On Language as such and on the Language of Man, Benjamin speculates that there is "a language of [technique] [...] that is not the specialized language of technicians" (SW 1, 62). ${ }^{30}$ Likewise, in his later writings, he alludes to the notion of technique as a language. In Theories of German Fascism, he argues that technique "gave shape to the apocalyptic face of nature and reduced nature to silence - even though this [technique] [...] had the power to give nature its voice" (SW 2, 319). ${ }^{31}$ 
17 A central aspect of Benjamin's early philosophy of language is the difference between immediacy (Unmittelbarkeit) and a means to an end. Language, for Benjamin, is never only a medium as a means to an end outside of itself. No language exhausts itself in being a medium for the transmission of information. Benjamin rejects any understanding of language declaring that "man is communicating factual subject matter to other men, for that does happen through the word by which he denotes a thing" (SW 1, 65). ${ }^{32}$ Language, in Benjamin's view, is not something through which but something in which something is communicated. But this intense communication isn't directed towards something outside of language. It is directed towards that non-place in language where language as a finite, profane and historical being is non-all. Every act of such an intense communication in language is purposeful for the immediate relation of language to that a-topos where it doesn't exist yet. Such communication corresponds over and over again to a fragmentary realization of an immediate relation to a universal language.

Benjamin's rejection of any instrumental notion of language echoes in his critique of the instrumentalization of technique by capitalist bourgeois society. According to its economic nature, the latter "cannot help insulating everything [technical] [...] as much as possible from the so-called spiritual, and it cannot help resolutely excluding [technique's] [...] right of determination in the social order" (SW 2, 312). ${ }^{33}$ Technique, here, is only ever a means to the purpose of exploitation and domination. In contrast to this Cartesian idea that man has the potential to be master and possessor of nature, for Benjamin, technique's purpose "is the mastery of not nature but of the relation between nature and man" (SW 1, 487). ${ }^{34}$ If technique has, like Benjamin argues, the power to give nature a voice, then it is also the key for a different design of the world.

Technique is a non-instrumental medium structured like a language. It has the potential to function as a common language for mankind and nature alike. The noninstrumental use of technique can be described as an intense communication not directed towards an end outside of the world but towards the non-all of a universal language of the world. Making a non-instrumental use of technique means to freely use it in order to playfully and constructively give shape to world oriented towards the idea of happiness. Such happiness, again, is not a state, not an end, but that non-place in the world where what is in the world is not yet. Happiness as the a-topos of the world is at the same time the a-telos of technique. It constitutes humanity's infinite task to which technique is the medium. Technique serves the intensive and fragmentary realization of happiness as the bodily intermingling of nature and man. Thus, for Benjamin, man possesses in technique "not a fetish of doom but a key to happiness" (SW 2, 321)..$^{35}$

\section{BIBLIOGRAPHIE}

Benjamin, Walter. 1991. Gesammelte Schriften II.1. 1977. Herausgegeben von Rolf Tiedemann und Hermann Schweppenhäuser. Frankfurt am Main: Suhrkamp. 
Benjamin, Walter. 1991. Gesammelte Schriften II.2. 1977. Herausgegeben von Rolf Tiedemann und Hermann Schweppenhäuser. Frankfurt am Main: Suhrkamp

Benjamin, Walter. 1991. Gesammelte Schriften III. 1972. Herausgegeben von Hella TiedemannBartels. Frankfurt am Main: Suhrkamp

Benjamin, Walter. 1991. Gesammelte Schriften IV.1. 1972. Herausgegeben von Tillman Rexroth. Frankfurt am Main: Suhrkamp

Benjamin, Walter. 1991. Gesammelte Schriften VI. 1985. Herausgegeben von Rolf Tiedemann und Hermann Schweppenhäuser. Frankfurt am Main: Suhrkamp.

Benjamin, Walter. 1991. Gesammelte Schriften VII.1. 1989. Herausgegeben von Rolf Tiedemann und Hermann Schweppenhäuser unter Mitarbeit von Christoph Gödde, Henri Lonitz und Gary Smith. Frankfurt am Main: Suhrkamp.

Benjamin, Walter. 1991. Gesammelte Schriften VII.2. 1989. Herausgegeben von Rolf Tiedemann und Hermann Schweppenhäuser unter Mitarbeit von Christoph Gödde, Henri Lonitz und Gary Smith. Frankfurt am Main: Suhrkamp.

Benjamin, Walter. 1996. Selected Writings Vol. 1, 1913-1926, eds. Marcus Bullock \& Michael W. Jennings. Cambridge, MA: Belknap Press of Harvard University Press.

Benjamin, Walter. 1999. Selected Writings Vol. 2, 1927-1934, eds. Michael W. Jennings, Howard Eiland, and Gary Smith. Cambridge, MA: Belknap Press of Harvard University Press.

Benjamin, Walter. 2002. Selected Writings, Vol. 3, 1935-1938, eds. Michael W. Jennings, and Howard Eiland. Cambridge, MA: Belknap Press of Harvard University Press.

Benjamin, Walter. 2003. Selected Writings Vol. 4, 1938-1940, eds. Howard Eiland \& Michael W. Jennings. Cambridge, MA: Belknap Press of Harvard University Press.

Lindner, Burkhardt. 1992. "Benjamins Aurakonzeption. Anthropologie und Technik, Bild und Text". In Walter Benjamin. 1892-1940, zum 100. Geburtstag, edited by Uwe Steiner, 217-248. Bern: Lang.

Pivecka, Alexander. 1993. Die künstliche Natur. Walter Benjamins Begriff der Technik". Frankfurt am Main: Lang.

Wohlfarth, Irving. 1998. "Der Zauberlehrling oder: die Entfesselung der Produktivkräfte. Zu einem Motiv bei Goethe, Marx und Benjamin". In Walter Benjamin. Ästhetik und Geschichtsphilosophie, edited by Gérard Raulet and Uwe Steiner, 165-198. Bern: Peter Lang.

Wohlfarth, Irving. 2002. "Walter Benjamin and the Idea of a Technological Eros. A tentative Reading of Zum Planetarium". In Perception and Experience in Modernity. Benjamin Studies 1, edited by Helga Geyer-Ryan et al., 65-110. Amsterdam, New York : Rodopi.

\section{NOTES}

1. In order to facilitate the browsing hypertext, we added into brackets intertitles that correspond to the logic of the original publication (Editor's note).

2. In order fo facilitate the location of Benjamin's citations quoted in this article, we have referred to the Selected Writings and to the Gesammelte Schriften with, respectively, SW and GS (Editor's note).

3. Translation modified by author. German original: "Die Ordnung des Profanen hat sich aufzurichten an der Idee des Glücks." (GS II.1, 203). 
4. German original: "In dieses Leben des Leibes der Menschheit, und somit in diesen Untergang und in diese Erfüllung vermag die Menschheit[,] außer der Allheit der Lebenden, noch partiell die Natur: [U]nbelebtes, Pflanze und Tier durch die Technik einzubeziehen, in der sich die Einheit ihres Lebens bildet. Zuletzt gehört zu ihrem Leben, ihren Gliedern alles was ihrem Glück dient." (GS VI, 80).

5. See, Paul Scheerbart: Lesabéndio (GS II.2, 618-620); Sur Scheerbart (GS II.2, 630-2); Zu Scheerbart. "Münchhausen und Clarissa» (GS VI, 147-8).

6. Translation of the author. German original: "Utopie des Leibes" (GS VI, 148).

7. Translation of the author. German original: "Pathos der Technik", "Pathos der Maschine" (GS VII.2, 880).

8. Translation of the author. German original: "Schöpfer von Maschinen und Erschaffer einer idealen Technik" (GS VII.2, 880).

9. Translation of the author. German original: "kein anderer Autor habe so den revolutionären Charakter der technischen Arbeit herauszustellen gewußt." (GS VI, 368).

10. German original: "allgemeine Versagen" (GS IV.1, 98)

11. See also Irving Wohlfarth (2002).

12. German original: "ein Versuch zu neuer, nie erhörter Vermählung mit den kosmischen Gewalten" (GS IV.1, 147).

13. German original: "Dies große Werben um den Kosmos vollzog zum ersten Male sich in planetarischem Maßstab, nämlich im Geiste der Technik." (GS IV.1, 147).

14. German original: "Weil aber die Profitgier der herrschenden Klasse an ihr ihren Willen zu büßen gedachte, hat die Technik die Menschheit verraten und das Brautlager in ein Blutrneer verwandelt." (GS IV.1, 147)

15. Translation modified by author. German original: "Jeder kommende Krieg ist zugleich ein Sklavenaufstand der Technik." (GS III, 238).

16. Translation modified by author. German original: "Und so auch Technik nicht Naturbeherrschung: Beherrschung vom Verhältnis von Natur und Menschheit." (GS IV.1, 147).

17. German original: "Mitbestimmungsrecht an der sozialen Ordnung", "harmonisches Zusammenspiel" (GS III, 238).

18. Translation modified by author. German original: "daß die soziale Wirklichkeit nicht reif war, die Technik sich zum Organ zu machen, daß die Technik nicht stark genug war, die gesellschaftlichen Elementarkräfte zu bewältigen." (GS III, 238).

19. See also Irving Wohlfarth (1998).

20. See also Burkhardt Lindner (1992); Alexander Pivecka (1993).

21. German original: "Mit den verschiedenen Methoden technischer Reproduktion des Kunstwerks ist dessen Ausstellbarkeit in so gewaltigem Maß gewachsen, daß die quantitative Verschiebung zwischen seinen beiden Polen ähnlich wie in der Urzeit in eine qualitative Veränderung seiner Natur umschlägt." (GS II.1, 484).

22. German original: "Die gesellschaftlich entscheidende Funktion der heutigen Kunst ist Einübung in dieses Zusammenspiel." (GS VII.1, 359).

23. Translation modified by author. German original: "Der Umgang mit dieser Apparatur belehrt ihn zugleich, daß die Knechtung in ihrem Dienst erst dann der Befreiung durch sie Platz machen wird, wenn die Verfassung der Menschheit sich den neuen Produktivkräften angepaßt haben wird, welche die zweite Technik erschlossen hat." (GS VII.1, 360)

24. German original: "die weltgeschichtliche Auseinandersetzung zwischen der ersten und zweiten

Technik" (GS VII.1, 368).

25. Translation modified by author. German original: "daß die erste Technik den Menschen so sehr, daß die zweite ihn so wenig wie möglich einsetzt. Die technische Großtat der ersten Technik ist gewissermaßen das Menschenopfer, die der zweiten liegt auf der Linie der 
fernlenkbaren Flugzeuge, die keine Bemannung brauchen. Das Ein für allemal gilt für die erste Technik (da geht es um die nie wiedergutzumachende Verfehlung oder den ewig stellvertretenden Opfertod). Das Einmal ist keinmal gilt für die zweite (sie hat es mit dem Experiment und seiner unermüdlichen Variierung der Versuchsanordnung zu tun)." (GS VII.1, 359).

26. German original: "mit unbewußter List daran ging, Abstand von der Natur zu nehmen." (GS VII.1, 359)

27. German original: "Er sieht sein Heil darin, die Massen zu ihrem Ausdruck (beileibe nicht zu ihrem Recht) kommen zu lassen." (GS VII.1, 382).

28. Translation of the author. German original: "hat viel Interesse daran, den Funktionscharakter der Technik so unkenntlich wie möglich zu machen." (GS III, 490).

29. Translation modified by author. German original: "Revolutionen sind Innervationen des Kollektivs: genauer Innervationsversuche des neuen, geschichtlich erstmaligen Kollektivs, das in der zweiten Technik seine Organe hat." (GS VII.1, 360)

30. Translation modified by author. German original: "einer Sprache der Technik, die nicht die Fachsprache der Techniker ist." (GS II.1, 140).

31. Translation modified by author. German original: "So prägte sie [die Technik], tief durchdrungen von ihrer eigenen Verworfenheit, das apokalyptische Antlitz der Natur, brachte sie zum Verstummen und war doch die Kraft, die ihr die Sprache hätte geben können." (GS III, 247).

32. German original: "er teile eine Sache anderen Menschen mit, denn das geschieht durch das Wort, durch das ich ein Ding bezeichne." (GS II.1, 144).

33. Translation modified by author. German original: "ihrer wirtschaftlichen Natur nach kann die bürgerliche Gesellschaft nicht anders, als alles Technische so sehr wie möglich vom sogenannten Geistigen abdichten, nicht anders, als den technischen Gedanken vom Mitbestimmungsrecht an der sozialen Ordnung so entschieden wie möglich ausschließen." (GS III, 238).

34. Translation modified by author. German original: "Und so auch Technik nicht Naturbeherrschung: Beherrschung vom Verhältnis von Natur und Menschheit." (GS IV.1, 147).

35. German original: "die an der Technik nicht einen Fetisch des Untergangs, sondern einen Schlüssel zum Glück besitzen." (GS III, 238).

\section{AUTEUR}

\section{JAN SIEBER}

Jan Sieber (1982-2018) was a teaching assistant and $\mathrm{PhD}$ candidate at the University of Arts, Berlin, Germany. He was also a member of the editorial board of the journal, for which he coedited in 2014 the $2^{\text {nd }}$ Issue, " The Persistence of Myth ", and in 2017 a Special Issue, « Discontinuous infinities ». 